\title{
Assessing the Tourism Destination Image of Taraba State Nigeria
}

\author{
E.G. Gonap*, O.B.B. Emmanuel and K. Madaki \\ Department of Hospitality and Tourism Management, Federal University Wukari, Nigeria
}

\begin{abstract}
Assessing the tourism image of a place, provide an important diagnostic insight into how people see tourism in a destination, which is a very important marketing tool for planning, development and promotion of the tourism industry. The aim of this study is to access the image of tourism in Taraba state and to suggest measures that can improve and sustain a positive tourism image for the state. The study was taken at five (5) sample tourist sites in which eight hundred (800) tourists were sample in the state using non proportional quota sampling technique. The study established that peace safety and security are prerequisite requirement for a positive destination image. The study also confirmed that Taraba state is very rich in tourist attractions which if adequately planned, developed, promoted well managed will make her one of the leading tourist destinations in Nigeria. However, the image of the state has rotated between positive when the state enjoyed peace, safety and security and negative during the incessant cycle of violent communal crisis that have befallen the state since 2002. To achieve a good attractive and sustainable tourism destination image of Taraba state the study made some recommendations to include religious, political and ethnic tolerance and understanding as well as provision of adequate security for sustainable peace enthronement good tourism planning, development and promotion.
\end{abstract}

Keywords: Destination, Image, Taraba State, Tourism, Perception

\section{Introduction}

According to the World Tourism Organization (WTO, 1980) all countries/destinations depend on their positive images to succeed as tourist destinations or their negative images to fail in attracting tourists. Hunt (1975) was the first to demonstrate the importance of positive "destination image" in increasing the number of tourists visiting destinations as much as, or even more than, tangible resources. Destination image is a key factor in the destination selection process of potential tourists; who, having a limited personal experience of the destination, act on the basis of their image of the destination, even if their perceived image does not necessarily coincide with objective reality (Gunn, 1988; Hunt, 1975). It is also a way to differentiate a destination from others with the same relative attributes and to enhance destination competitiveness. This is why destination image is one of the current issues in tourism marketing and tourism surveys.

The tourism industry has a great physical/environmental and socio- economic influence on a destination, especially regarding marketing its image and influencing tourists' destination choice. A good image of a destination brings more tourists to the destination (WTO, 1980). If any tourism authority can therefore create a positive image of its destination in tourists' minds, then it is easy to be successful in her tourism business (Hankinson, 2004) because a strong positive destination image gives a competitive advantage to a destination against other competitors (fall, 2004). If the tourists perceive the image of a potential destination positively and favourably, then they are often likely to visit the desired tourist place even many times (Laws, 2006; Beerli, 2004).

According to Hall and Sullivan (2004), there are three essential factors that help to build a destination image. First is word-of-mouth by the tourists and residents. If positive word of mouth is spread about a destination, then it is easy to build a strong image of the destination. Secondly, image making by media (print and electronic) and lastly, policies and interests taken by destination managers. If the management of a particular destination takes initiative to build a positive destination image and work accordingly with it, then it helps to build an attractive destination image of the tourist place. A positive destination image enhances the chance to choose and visit the 


\section{E.G. Gonap et. al. / Assessing the Tourism Destination Image of Taraba State Nigeria}

destination. Tourism destination image therefore has been proven to be a very critical factor in people's decision process. Researches of the past two decades have demonstrated that image is a valuable concept in understanding the destination selection process of tourists.

Image is defined as a perceptual phenomenon formed through a consumer's reasoned and emotional interpretation, which has both cognitive (beliefs) and affective (feelings) components (Konecnik, 2004). Perceptual or cognitive evaluation refers to beliefs and knowledge about an object/place whereas affective evaluation refers to one's feelings about it. Affective components are basically emotional responses concerned with feelings and meanings attached to a destination (Baloglu\&Brinberg 1997; Gartner 1993; Walmsley\& Jenkins 1993).

According to Sonmez and Sirakaya (2002) if a destination is interested in developing a sustainable tourism industry in a period of increasing competition, then it needs a clear understanding of tourists' images (of the destination) to develop a successful positioning strategy in the competitive marketplace. Central to destination marketing is the way in which the image is perceived and acted upon by potential tourists as it is often perceived, rather than reality that motivates tourists to visit a destination (Andersen, 1984). The tourist marketer's goal is to match the promoted image and the perceived image in the consumer's mind to avoid a distorted destination image. Indeed, lack of knowledge of a destination's appeal from the perspective of potential tourist markets hinders the development of a destination's image. The creation of a distinctive and unique destination image in the tourism industry plays a vital role in positioning the destination in the consumer's mind and holds the key to destination differentiation. An important step in the destination management process is an understanding of the attitudes of actual and potential visitors of a destination (Deslandes, 2006). Consequently, tourism destination images are important because they influence both the decision-making behaviour of potential tourists and the levels of satisfaction regarding the tourist experience (Jenkins, 1999). An accurate assessment of perceived destination image is a prerequisite to designing an effective marketing strategy and helps the destination marketer to offer what its visitors are expecting and create more realistic expectations, if necessary.

Each person's perceived image of a particular place is unique, comprising their own memories, associations and imaginations of a particular place (Jenkins, 1999). Therefore, the perceived image of a destination is influenced by the characteristics of the individuals and is formed through image projected by the destination and the individual's own needs, motivations, prior knowledge, preferences and other personal socio-economic and demographic characteristics. In that way, the individuals build their own mental picture of the tourist destination, which gives rise to their own, personal perceived images (Asworth\&Voogd, 1990; Bramwell\&Rawding 1996; Gartner, 1993).

The personal factors that influence perceived images include gender, age, level of education, family life cycle, social class, place of residence/origin, religion, ethnicity as well as those of a psychological nature (motivations, values, personal life cycle, etc). These personal factors affect the individuals' cognitive organization or evaluations of stimuli and therefore also influence the perceptions of the environment and the resulting image (Beerli\& Martin, 2004).

\section{Statement of the Problem}

Over the years, Taraba state has been widely known and acknowledged as a tourist haven of both natural and cultural uniqueness and beauty. The state has been referred to as a land of very beautiful, unique natural sceneries, rich and colourful cultural and historical heritages, clement weather as well as very hospitable and peace loving inhabitants. The state is therefore frequently described with phrases such as 'tourist haven', 'Nature's gift to the Nation', 'The Scenic Manbilla Plateau , 'a miniature Nigeria' and 'a home of unity in diversity' among other sobriquets that describe her attractiveness - all as her tourism brand names. For quite a long time, the image of the state had been positive and favorable. It was the preferred destination choice of many tourists, both national and international. For example, when Nigeria launched its image laundering efforts, "Good People, Good Country" in the early 2000s, the Manbilla Plateau Taraba State graced the cover of its 
international presentations and the official website of the campaign. From all over the country (Nigeria), the capital city of Taraba State was a preferred venue for national and international conferences, seminars and workshops for both public and private sectors. And for quite a long time, Taraba State lived up to its selfproclaimed sobriquet as the "Home of Peace and Tourism." Unfortunately, this positive and favorable image has been dented by recent fatal communal crises and conflicts that have overtaken the "peaceful" nature that the state had come to be known for, and marred the tourist attractiveness that the state had been acclaimed for.

Between 2002 and 2019, Taraba state has been embroiled in series of communal crises and conflicts that have resulted in the death of thousands of people and destruction of properties worth billions of naira. Associated with this has been the assumed loss of the positive image that the state had groomed over the years. Many residents have relocated to other preferred destinations and stream of tourists, visitors and new residents had dwindled. The reputation of the state as a peace and tourist haven has suffered calamitously, nationally and internationally, especially since the colourations of the conflict are religious and ethnic and bothering on the very essence of the Nigerian Constitution and its nationhood (the question of "Indigeneship"). These incessant conflicts with their deadly outcomes have catapulted Taraba State into international limelight as a flash point of violence and ignited an irrepressible debate in Nigeria on religion, ethnicity and nationhood. Importantly, it has raised and sustained the "Question of Indigene ship" in Nigeria and its place in the Constitution and therefore its role in nation building. The fact that these are emotional and sentimental issues has not helped the debate move forward on logical grounds. It has pitched one camp against another and elicited both sympathy and condemnation from across the country, based on general grounds of religion, ethnicity and geographic origin in the country. Needless to say, the infamy has not done Taraba State any favours in terms of its perceived image as tourist destination. Anecdotal evidence from newspaper and news reports, internet sources and other social media suggest that Taraba State no longer enjoyed the prime status it had as a tourist destination in Nigeria.

Today Taraba State is in the process of rebuilding its image as a tourist haven and a peaceful and hospitable state. To develop a successful marketing framework and strategy that would launder and reconstruct its assumed dented perceived image into a positive and favourable image, it requires important information on several issues: some knowledge about its perceived image - what it was before the crises, how much dent has been created by the unfavorable circumstances, and what the current perceived image is in the present reconstruction efforts, which will guide the direction and magnitude of image projection required; and also, an understanding of the factors that would influence tourists' perceived image of the state. These factors include personal socioeconomic and demographic characteristics of tourists, including their religious affiliations, and the geographic origin of tourists and how they influence perceived image of Taraba State. These are interesting yet challenging research issues that have not yet been addressed in the tourism industry of Taraba State. The silent research questions asked were:

1. What is the perceived tourism destination image of Taraba State at different time profiles?

2. What factors influence or account for the image perceived?

3. How does source of information influence the destination image of Taraba State by tourist?

\section{Aim and Objectives of the Research}

The main aim of this study is to investigate the tourism destination image of Taraba State. To achieve this aim the followings are the objectives:

1. To analyze factors that influence and/or account for the tourism destination image of Taraba State.

2. To find out sources and types of information about Taraba State to tourists.

3. To determine the socio-physical characteristics of tourist that visit Taraba State and to establish the influence of these characteristics on image formation. 


\section{Scope of the Study}

It is imperative to delineate the topical, geographical and time scopes of the study as it was impossible within the constraints of time and other resources to cover everything related to the topic. Thus the scope of the study was defined as follows:

Topically, issues covered invariably include concepts that focus mainly on destination image perception, influences of socio physical factors (religion, distance decay function and general peace profile of Taraba State on her perceived tourism destination image).

The study was also confined to an assessment of the perceived tourism destination image of Taraba State by domestic tourists found in Plateau State only. Furthermore, the tourists covered were both domestic and international tourists that had attained the age of 18 years and above found at selected tourist sites in Taraba State at the time of the study.

\section{Significance of the Study}

This study has the potential for replication in in other states or tourist destinations and importantly, could be a significant input in a national framework on marketing Nigeria's image as a tourist destination. This is important as the image problems being faced in Taraba State are reflective of the image problems being confronted by the country as a tourist destination.

\section{Literature Review}

\section{Conceptual and Theoretical Frameworks on Tourism Destination Image}

Pearce (1982) defines tourism as "relationships and phenomena arising out of the journeys and temporary stays of people traveling mainly for recreation." The spatial interaction arising out of the tourist's journey (movement) from his/her place of origin to destination is important in understanding the phenomenon of tourism and differentiates it from other forms of leisure such as in homes and places of work

Tourism is a multi-faceted phenomenon, which involves movement to and stays in destination(s) outside the normal place of residence for the purpose of recreation, and comprises of three basic elements:

1. A dynamic element which involves travel to a selected destination;

2. A static element which involves the stay in the destination; and

3. A consequential element resulting from the two proceeding elements which is concerned with the effects on the economic, physical and social subsystems with which the tourist is directly or indirectly in contact with (Mathieson, 1982)

The term 'tourist' is in principle interpreted to mean "any person traveling temporarily for a period of twenty four hours or more to an area other than the one he resides or works" and shall include those travelling for pleasure and health, for international meetings, conferences, businesses (as most businesses combine pleasure), and religious pilgrims but not to take up permanent residence at the destination (Robinson, 1979). A tourist destination refers to a place visited by a tourist. A destination is the basic geographic unit used for production of tourism statistics. Within the reference country, the country might be split up into destination areas which represent homogenous tourism regions or which may be groups of local government administrative regions. In this study Plateau State is seen as a designated tourist destination within Nigeria.

Tourist destination thus can be a particular resort or town, a region or a country, or even a larger area of the globe. In some cases, according to Holloway (1994), the destination can be highly precise as in the case of a 
hotel, which provides a range of leisure facilities on site. In such cases, it may be the tourist's objective to visit the hotel purely and simply because of the facilities the hotel provides and the entire stay will be taken up to enjoy these facilities alone. He further asserts that success of destinations in attracting tourists will depend upon the quantity and/or quality of three essential benefits that they offer: attractions, amenities (or facilities) and accessibility or ease of getting to the destination.

There are two types of destinations: natural or man-made. Most of either type of destinations are managed to enhance their attractiveness. The more attractions a destination can offer, the easier it becomes to market that destination to potential tourists. Analyzing attractions is however not easy especially when one recognizes that what appeals to one tourist may actually deter another.

In the description of destinations, many attractions are physical features of that destination such as the beauty of mountains, the fresh air, the uniqueness of the landscape in addition to numerous man-made and purposively built attractions to increase the pulling power of a destination (Holloway, 1994). It must be noted that the attractiveness of a destination is in the tangibles and intangibles and is dependent on the image that potential tourists' have of it. For instance, India will be seen by one group of travelers as exotic and appealing while others will reject the destination because of its poverty or its alien culture.

Amenities are those essential services catering for the needs of the tourists. These include accommodation and food, local transport, information centers and the necessary infrastructure to support tourism: roads, public utility services, information posts, and parking facilities etc.

Accessibility of a destination will facilitate the visits of tourists. While the more intrepid travelers may be willing to put themselves to great inconvenience and risks in order to see some of the more exotic places in the world, most tourists will not be attracted to a destination unless it is relatively easy to reach. Accessibility is a function of high route connectivity (air, rail, road and waterways), centrality, network density, route condition, flexibility and available means of transportation.

All these three elements (attractiveness, amenities and accessibility) are important in shaping an image of the destination in the minds of tourists. Basically, tourism is an industry based on imagery; its overriding concern is to construct, through multiple representations of paradise, an imagery of the destination that entices the outsider to place himself or herself into the symbol-defined space, which in his or her mind is a place that he/she perceives as different from other destinations offering similar primary attractions (Ahmed, 1997). Destination image is therefore usually conceived as the tourists' and buyers' perceptions of the attributes or attractions available within a destination area (Gartner, 1989). Naturally, an image conceived by an individual can be positive or negative or even mixed depending on the experience or information that an individual has received (Kotler, 1993). The destination image therefore plays crucial role in designing marketing strategies for a destination as it is a critical component in destination selection process of potential tourists (Baloglu, 1997; Bramwell \& Rawding, 1996).

The most commonly cited definition for tourist destination image is that by Crompton (1979): "the sum of beliefs, ideas and impressions that a person has of a destination". This definition relates to the individual. Some other definitions, however, acknowledge that images can be shared by groups of people. For example, Echtner and Richie (1993), defines destination image as "the expression of all objective knowledge, impressions, prejudice, imaginations, and emotional thoughts an individual or group might have of a particular place." This definition encompasses both the personal and stereotyped images shared by groups, which from a marketing point of view, affords the segmentation of markets and facilitates the formulation of marketing strategies. This study therefore adopts this definition as more suited to its broad aim of providing information to help develop a marketing strategy for enhancing the image of Plateau State as a tourist destination. 


\section{Materials and Methods}

\section{The Study Area}

Taraba State lies within the middle belt region and North East of Nigeria and is located within 90.350 and $110.30 \mathrm{o}$ east of the Greenwisch meridian and latitude 60.30 o north of the equator. It has a landmass of about $60,000 \mathrm{sqkm}$ which is about $6.6 \%$ of the nation land mass.

Taraba State is rightly tagged nature gift to the nation. It is an undeniable fact that there is no better natural gift to the nation in Nigeria than Taraba State. The state is criss-crossed with rivers, streams, waterfalls and springs. It is characterized by two types of climate - the temperate climate on the Mambilla Plateau and the tropical climate in other parts of the state. It is a state blessed with fertile farm land and abundant forest resources.

To preserve the forest and enormous resources therein, Taraba State government has forty-nine (49) forest revers, ninety-eight (98) plantation and three (3) major game reserves including the famous Gashaka Gumti National Park. Other tourist attractions in the state are Zing holiday resort, the Maihula mountain, the Waterfalls, Nwonyo fishing festival, the famous Mambilla Plateau, Marmara crocodile pond, special rock features etc. such beautiful environment in Taraba State has encourage the establishment of these tourist centres which further reinforces the attractiveness of Taraba State to visitors.

\section{Methodology}

The research was restricted to, five tourist resort in Taraba State; such as the Gashaka Gumti National Park, Rufu Rock and Water Fall, the Marmara Crocodile Pond the Zing Holiday Resort and the Scenic Mambilla Plateau. Data were collected from management of each tourist resort through interviews, field observation and questionnaires. Eight hundred (800) questionnaires were administered to various respondents at the attraction sites and residential areas within the study environment using non proportional quota sampling technique. The quotas were selected variable of the population which influences image perception in the past studies as reveal in the introduction. The study population comprises of all the dornstic and international tourist found at the sampled tourist sites.

In the quota sampling, a population is sub-divided into classes or categories (variables) as the survey proceed, not prior to sampling because the probability of a respondent been selected is not known. This means the classes are not mutually exclusive. In this study, which used quota sampling, the researchers obtained respondent from various income categories, religious group, educational status, age groups and different geographical regions from which the tourist came to Taraba State.

\section{Results and Discussion}

\section{The Perceived Tourism Destination Image of Taraba State}

The goal of this study was to establish the perceived tourism destination image of Taraba State. But as earlier noted in the introduction, image perception can be measured a priori, in situ or a posteriori. This particular study adopted the in situ perception assessment procedure. In this approach, the study assessed the tourism destination image of Taraba State by the tourists that were found at the selected tourist sites in the state. The researcher however, also asked the sampled tourists about their perception of the image of Taraba State. The following subsections are the finding on the perceived tourism destination image of Taraba State by the 800 sampled tourists in the state.

Perceptions of Tourists about the Tourism Attractiveness of Taraba State Before, During and After each Cycle of Communal Crises 
The sampled tourists were first asked their general feelings about the tourism attractiveness of Taraba State before, during and after each cycle of ethno-religious crisis experienced in the State. The table 1 below shows a significant shift in the perceived tourism image of Taraba State at the different time profiles (pre, during and the post cycles of ethno-religious/communal crises) witnessed in the State. While over $75 \%$ of the sampled tourists said that Taraba State was an attractive tourist destination before the eruption of the incessant ethno-religious crises, only about $7 \%$ of the sampled tourists felt that the State was still an attractive tourist destination during the crises periods, while about $51 \%$ of respondents felt that the State wore a negative (unattractive) tourism image during the periods of ethno- religious crises.

Furthermore, the Table shows that most of tourists (about 25\%) changed their image of Taraba State from being positive (attractive) to being negative (unattractive)after the post crises period about $7 \%$ maintaining that the State was still attractive during the sectarian crises. This finding shows significant changes in image perception about Taraba State from pre-crisis period to crisis period.

Table 1: Tourists' Perceptions about the Attractiveness of Taraba State Before, During and After Each Cycle of

\begin{tabular}{|c|c|c|c|c|}
\hline $\begin{array}{c}\text { Attractiveness of Taraba } \\
\text { State }\end{array}$ & $\begin{array}{c}\text { Taraba State } \\
\text { was attractive }\end{array}$ & $\%$ & $\begin{array}{c}\text { Taraba State } \\
\text { was } \\
\text { unattractive }\end{array}$ & $\%$ \\
\hline Pre Crises Periods & 600 & 75 & 190 & 24 \\
\hline During the Crises Periods & 60 & 7 & 410 & 51 \\
\hline Post Crises Periods & 140 & 18 & 200 & 25 \\
\hline Total & 800 & 100 & 800 & 100 \\
\hline
\end{tabular}

Ethno-Religious Crises

Source: Fiedwork 2020

It can be said that since the emergence of democratic rule in Nigeria in 1999, Taraba State has become a "permanent" flashpoint of violent clashes. The State, which had hitherto been one of the most peaceful in Nigeria, has been deeply enmeshed in political and ethno-religious conflicts characterized by genocidal attacks, maiming and killings of several persons, loss of business investments, and property worth several billions of Naira. Within the spate of about fourteen years, several violent political and ethno-religious conflicts have been reported in Taraba State and all efforts to restore peace are yet to achieve the desired end. It would seem that democracy has increased the culture of impunity in some people while political differences are believed to have fueled some of the violence that has erupted. For over a decade, the profile of Taraba State as "tourist haven" suffered greatly. The thrust of this study therefore, is to investigate the tourism destination image of Taraba State before, during and after the sectarian raids in the state.

Arising from these cycles of bloody sectarian crises, an assessment of the people's perception and feelings about the state as a tourist destination over these different time profiles is very crucial and critical All things being equal one would expect that a peaceful period at a destination should project and impress a positive image to the visitors while a crisis period would send out negative/bad image

The situation however is gradually improving after the crises as peace measures were intensively mobilized and substantial peace was regained.

\section{Factors That Influence the Perceived Tourism Image of Taraba State}

The sampled tourists were asked to enumerate the probable factors that they felt had negatively affected the image of the state as a tourist destination at the time they were already visiting the state. The factors they listed, which are mutually inclusive, are summarized on Table 2 below 


\section{E.G. Gonap et. al. / Assessing the Tourism Destination Image of Taraba State Nigeria}

The most cited factor that affected the tourism image of Taraba State, according to the sampled tourists, is the incessant ethno-religious crises that had engulfed the state since 2002. Other significant factors that have impaired the tourism image of Taraba State include: poor marketing and promotion, poor infrastructural development and planning, low private investment and outright neglect of the tourism industry, abuse and misuse of spectacular tourist attractions/potentials.

Ever since the eruption of violent ethno-religious clashes in the state in 2002, the news report about the crises have occupied the front pages of newspapers/magazines and news headlines on television and on the radio. Some of the news reportage have been highly exaggerated and biased just to buy cheap popularity to unceasingly pitch the followers of different faiths against each other. More than two-thirds of the tourists agreed that some of the news report were false, without any iota of truth, while a lot more exaggerated the religious colourations to serve some propaganda and political agenda to sustain mutual mistrust and sow deep hatred among the opponents. Many counter press releases and endless peace conferences were held as efforts to correct the wrong reports. News items about the situation were quite confusing and largely inaccurate as news items by same media sources later contradicted their earlier reports. Some of the tourists alluded to deliberately bias propaganda reported by some news media. It was really a trying period for the image of Taraba state, especially as a tourist destination.

Table 2: Factors that Negatively Affect the Tourism Image of Taraba State

Factor

Ethno Religious Clashes and insurgency (Insecurity)

Poor Marketing and Promotion

Low Private Investment

Bias and subjective News Reports

Poor Infrastructural Development

Abuse of Attractions e.g.- quarrying, farming

Poor Planning

Lack of Government Interest

Poor Supra structural Facilities

Filthy (Dirty) Environment

$$
\begin{aligned}
& \text { Number of Tourists } \\
& \qquad \mathrm{N}=800
\end{aligned}
$$

150

140

120

100

80

75

50

35

30

20
$\%$

9

6

5

4

3

Source: Fieldwork 2020

\section{Knowledge of and Visits of Sampled Tourists to Taraba State}

The 800 sampled tourists at various tourist sites in Taraba State were interviewed on a wide range of issues regarding their knowledge of, visits to, and perceptions about image of Taraba State as a tourist destination in Nigeria. Findings are presented in this section.

\section{The First Time the Tourists Heard about Taraba State}

Tourists can only perceive of a tourist destination they have heard or visited and known about its tourism attributes and other image-influencing incidences therein. The sampled tourists were asked when they first heard about Taraba State since its creation in the year 1991. Responses are presented on Table 3. 
Table 3 shows that about nine-tenth of the sampled tourists heard about Taraba State between 1992 and 2002. About one-tenth of the tourists however, happened to know about the region (Taraba State) as part of the defunct Gongola State in the mid-1970s to 1980s.

Table 3: The Time the Tourists First Heard About Taraba State

Time Number of tourists \%

\begin{tabular}{ccc}
\hline $1992-2002$ & 220 & 28 \\
$2003-2011$ & 480 & 60 \\
$2012-2019$ & 100 & 12 \\
\hline Total & 800 & 100
\end{tabular}

Source: Fieldwork 2020

\section{What the Tourists First Heard about Taraba State}

An outstanding thing the tourists heard about Taraba State can impress or discourage them on the tourism image of the State. The researcher asked the tourists to identify one outstanding thing they first heard about Taraba State. It is interesting to note that about $26 \%$ of the tourists heard that Taraba State is a nature gift to the nation region, while $24 \%$ of the tourists heard about it as a tourist destination, which has good climate/weather, scenic features and a peaceful State. These disclosures must have positively impressed on the tourism image of the State.

About $13 \%$ of tourists however, first heard of the State as a crisis-torn region because of the 2002-2019 ethnoreligious crises, which had catapulted the state into national and international discourses on ethno-religious conflicts in developing economies. This suggests that the state may have projected different images to different people before, during and after the bloody communal crises.

Table 4: One Outstanding Thing that Tourist First Heard about Taraba State:

\begin{tabular}{ccc}
\hline $\begin{array}{c}\text { What tourists first heard about } \\
\text { Taraba State }\end{array}$ & Number of tourists \\
\hline Natures gift to the nation & 210 & 26 \\
Tourism destination State & 190 & 24 \\
A State with good climate/weather & 185 & 23 \\
Crises torn State/region & 105 & 13 \\
A peaceful State & 80 & 10 \\
The food basket of the nation & 30 & 4 \\
\hline Total & 800 & 100
\end{tabular}

Source: Fieldwork 2020 


\section{Knowledge of Tourists about Taraba State as at the Times of their Visits to the State}

The image formed of any tourist destination is the consequence of two closely interrelated components: Perceptive/cognitive evaluations, which refers to individual's own knowledge and beliefs about an object or a place, and affective appraisals, which refer to the individual's feelings towards the object or a place attributes. The sampled tourists were asked to disclose their general feelings about Taraba State as at the times of their visits to the state.

Table5 below shows that at the time of their visits to the state, over $19 \%$ had the feeling that Taraba State was peaceful and rich in tourism potentials including clement weather/climate. Only $14 \%$ of the tourists felt that Taraba State was a crises-torn State.

Table 5: Perceptions of Tourists about Taraba State at the Times of their Visits to the State

\begin{tabular}{ccc} 
Feelings & $\begin{array}{c}\text { Number of Tourists, } \\
\text { N=800 }\end{array}$ & $\%$ \\
\hline Rich tourism attractions & 330 & 41 \\
Good weather/climate & 210 & 25 \\
Peaceful and hospitable people & 150 & 19 \\
Crises prone area & 110 & 14 \\
\hline
\end{tabular}

Source: Fieldwork 2020

\section{Conclusion}

The study has investigated and established that the perceived tourism destination image of Taraba State is highly dynamic and is influenced by one or a combination of the following factors namely: richness, attractiveness and uniqueness of tourist attractions in the State, peace profile (absence or presence of communal crises and terrorism/insurgency that rocked and befell Taraba State severally). The study revealed glaringly that peace does not symbiotically coexist with any violent crisis. Image perception is thus a reciprocal of image Projection. Taraba State was perceived positively in terms of her rich and unique tourism attributes. In contrast, incidences such communal crises and terrorism/insurgency, which received negative reportage painted Taraba State with negative or mixed images. The image formed can be positive/desirable/favourable or negative/undesirable/unfavorable or unclear/confused/ mixed/neutral at any point in time.

\section{Limitation of the Study}

Research works are most often surrendered by a lot of hindrances, which impedes the progress of the research as well as generally truncate the expectations of the research. Some of these hindrances includes:

1. Time Constraint: the time although seeming too much, can never be enough to conduct a research. A research being a continuous search for solutions to problems, is most often conducted within a limited period of time, in this aspect, there was not enough discretionary time to conduct the research.

2. Distance of the Resorts: the study area, Taraba State is very large as such the movement from one tourist site to another was not easy as it's constantly require money for transportation.

3. COVID-19 Pandemic: COVID-19 Pandemic is also a limitation.

\section{Recommendations}

Arising from the findings of this study, the following recommendations were made: 
Taraba State as a tourist destination should strive to aggressively project positive tourism destination image through regular and sustained promotion campaigns. Destinations with unique, positive, alluring and inviting images are usually in the forefront of being considered despite battered images.

Towards enthroning a sustainable and attractive tourism destination image of Taraba State, the researcher recommends more peace yielding measures to include: religious tolerance, political understanding, ethnic integration and unity, provision of adequate security, good planning and development, objective and truthful news reportage about incidences in the state as well as sustainable marketing and promotion strategies which will all boost and sustain peace and good tourism destination image for Taraba State. In providing security measures for risk reduction, the stakeholders in the tourism industry of Taraba State should during crises periods engage the services of the Joint Security Task Force (JSTF) comprising of Nigeria army, air force, navy, police and the civil defense corps to protect lives, physical facilities, equipment, premises and activities areas and where it is necessary, provide security fence.

It was found that Taraba State conducted only few studies on its destination, none of these studies focused on destination image promotional activities (Image projection and image perception studies) such studies are strongly recommended by this study to know how the state's promotional activities are projected and perceived positively.

Despite the fact that Taraba State renowned for its tourism attractions, however, the emergence of violent communal clashes and terrorism (insurgency) are argued to have perplexed the state image. This should be squarely addressed by the Security Agents.

\section{References}

Andersen, L. (1984). Projected and perceived Image of Spain seize to tourist destination for British Travelers.Journal of Travel and Tourism Marketing,9(4), 47-66

Ashworth, G.J., \&Voogd, H. (1990). Selling the city, marketing approaches in public sector urban planning, London: Belhaven Press.

Beerli, A. \& Martín, J.D. (2004a) Tourists' characteristics and the perceived image of tourist destination: A quantitative analysis - A case study of Lanzarote, Spain.Tourism Management, 25, 623-636.

Baloglu, S. \&Brinberg, D. (1997). Affective images of tourism destinations. Journal of Travel Research, 35(4), 11-15.

Bramwell, B., \&Rawding, L. (1996). Tourism marketing images of industrial cities. Annals of Tourism Research, 13 (1), 201-221.

Deslandes, D.D. (2006). Measuring destination image: Do the existing scales work? Tourism Review International, 10(3), 141-153

Fall, L. (2004). The increasing role of public relations as a crisis management function: An empirical examination of communication restrategising efforts among destination organisation managers in the wake of 11th September, 2001.Journal of Vacation Marketing, 10(3), 238-252.

Gartner WC (1993). Image formation process. Journal of Travel and Tourism Marketing. 2(3), 191-215.

Gunn, C. (1988). Vacationscapes: Designing tourist regions. New York, Van Nostrand Reinhold.

Hall, C. M., \&Sullivan, C. (2004). Travel Safety, Terrorism and the Media: The significance of the issueattention cycle.Current Issues in Tourism, 5(5), 458-466

Hankinson, G. (2004). Relational network brands: Towards a conceptual model of place brands. Journal of Vacation Marketing, 10(2), 109-121.

Hunt, J. (1975). Image as a factor in tourism development. Journal of Travel Research, 13(3), 1-7.

Holloway A. (1994). Tourist oerception of Finland and selected European countries as travel destinations. European journal of marketing, 12(2)34-42.

Jenkins, O. H. (1999) Understanding and measuring tourist destination images.International Journal of Tourism Research,1, 1-15. 
Konecnik, B. (2004). Institutions, research and development: tourism and the Asian financial crisis.International Journal of Tourism Research, 2(2), 133-136.

Laws, E., Cooper N. (2006). Synergies in destination image management. A case study and conceptualization. The international Journal of Tourism Research, 4 (1), 39-55

Mathieson A. all G (1982). Tourist: Economic, Pysical and Social Impacts. London: longman.

Pearce P.L (1982) the Social Psychology of Tourist Behavior. International Series in Experimental Social Psychology. Vol. 3. Oxford: New York: Pergamon press.

Sirakaya, E., Sönmez S., \& Choi, H. (2001). Do destination images really matter?: Predicting destination choices of student travelers. Journal of Vacation Marketing, 7(2), 125-142.

Sirgy, J.M., \& Su. C. (2000). Destination image, self-congruity, and travel behavior: toward an integrative model. Journal of Travel Research, 38(4), 340-352

Sönmez, S. \&Sirikaya, E. (2002).A distorted destination image? The case of Turkey.Journal of Travel Research, 41 (2), 185-196.

World Tourism Organization (1980). Tourist images. Madrid, WTO.Retrieved from http://media.unwto.org/en/press-release/2012-12-12/international-tourism-hits-one-billion (15th April, 2014).

World Tourism Organization (2000). Tourism 2020 vision: East Asian and Pacific. Retrieved from https://www.media.unwto.org/en/press-release/2012-12-12/international-tourism-hits-one-billion (15th April, 2014) 